\title{
Rancang Bangun Sistem Informasi Penjualan Sparepart dan Jasa Servis Motor
}

\author{
Delviani Kurniawati Djami ${ }^{1 *}$, Ferdinandus Lidang Witi ${ }^{2}$, Anastasia Mude ${ }^{3}$ \\ ${ }^{1,2,3}$ Sistem Informasi, Teknologi Informasi, Universitas Flores, Ende, Indonesia \\ Email: $\underline{1}$ delfhyanidjami@gmail.com, ${ }^{2}$ ferdylidang2017@gmail.com, ${ }^{3}$ annmude87@gmail.com
}

\begin{abstract}
Benneta Motor Workshop is one of the individual businesses that was founded in 2017, engaged in the business of selling motorcycle spare parts and servicing services. In running its business, Benneta workshop still uses conventional systems so that there are several obstacles found starting from the data management process, purchase transactions, sales and service services, to the process of making reports which are still recorded manually in notes and stored in a ledger so that it is still less efficient. in terms of time and process. Conventional systems cause the data to be inaccurate and not fast in recording so it takes a long time to do it. The purpose of this research is to build an information system for selling spare parts and motorcycle service using Visual Basic.Net programming language and MySQL database. In this study, the authors used a qualitative descriptive research method. The design method used in this application uses the waterfall method and the testing method used by the author is blackbox testing. With the creation of this system, it is hoped that it will provide efficiency and work effectiveness at the Benneta Motor Workshop.
\end{abstract}

Keywords: Information System, Visual Basic.Net, Spare Part Sales, Service, Waterfall.

\begin{abstract}
ABSTRAK
Bengkel Benneta Motor merupakan salah satu usaha perseorangan yang didirikan pada tahun 2017, bergerak di bidang usaha penjualan sparepart dan jasa servis sepeda motor. Dalam menjalankan bisnisnya, bengkel benneta masih menggunakkan sistem konvensional sehingga terdapat beberapa kendala yang ditemukan dimulai dari proses pengelolaan data, transaksi pembelian, penjualan dan jasa servis, hingga proses membuat laporan yang masih dicatat manual dalam nota dan disimpan ke dalam buku besar sehingga masih kurang efisien dari segi waktu dan proses. Sistem konvensional menyebabkan data data menjadi tidak akurat dan tidak cepat dalam melakukan pencatatan sehingga memerlukan waktu yang lama untuk mengerjakannya.Tujuan dari penelitian ini adalah membangun sistem informasi penjualan sparepart dan jasa servis motor dengan menggunakan bahasa pemrograman Visual Basic.Net dan basis data MySQL. Pada penelitian ini penulis menggunakan metode penelitian deskriptif kualitatif. Adapun metode perancangan yang digunakan dalam aplikasi ini menggunakan metode waterfall dan metode pengujian yang digunakan penulis ialah blackbox testing. Dengan adanya pembuatan sistem ini diharapkan akan memberikan efisiensi dan efektifitas kerja pada bengkel benneta motor.
\end{abstract}

Kata Kunci: Sistem Informasi, Visual Basic.Net, Penjualan Sparepart, Jasa Servis, Waterfall.

\section{Pendahuluan}

Di era globalisasi saat ini kebutuhan akan teknologi informasi kian meningkat. Banyak perusahaan yang menggunakan teknologi informasi sebagai sarana untuk menjalankan proses bisnisnya agar meningkatkan kualitas pelayanan dari perusahaan itu sendiri. Dari perkembangan teknologi itulah kita harus memahami serta mengenal teknologi tersebut. Dimana kecanggihan teknologi akan terus berkembang dengan pesat di berbagai aspek kehidupan dimasa yang akan datang [1].

Dengan perkembangan teknologi informasi saat ini, pengelolaan proses bisnis dapat dilakukan secara lebih optimal bila memanfaatkan teknologi informasi salah satunya ialah bisnis bengkel[2]. Bengkel Merupakan suatu tempat atau ruangan yang digunakan untuk melakuakan perbaikan, perawatan, pemeliharaan serta merancang dan merakit suatu mesin, yang mana dalam 
bengkel tersebut terdapat alat-alat kontruksi serta onderdil dari mesin tersebut. Sedangkan pengetahuan dan keterampilan tentang bengkel bisa disebut juga perbengkelan[3].Penggunaan teknologi informasi bertujuan untuk mempermudah dalam mengelola informasi dan tingkat keakuratan informasi.

Bengkel Benneta Motor merupakan salah satu usaha perseorangan yang didirikan pada tahun 2017, bergerak di bidang usaha penjualan sparepart dan jasa Servis sepeda motor. Dalam menjalankan bisnisnya , bengkel benneta masih menggunakkan sistem konvensional sehingga terdapat beberapa kendala yang ditemukan dimulai dari proses pengelolaan data, transaksi pembelian, penjualan dan jasa Servis, hingga proses membuat laporan yang masih dicatat tangan (manual) dalam nota dan disimpan ke dalam buku besar sehingga masih kurang efisien dari segi waktu dan proses. Sistem konvensional menyebabkan data-data menjadi tidak akurat dan tidak cepat dalam melakukan pencatatan sehingga memerlukan waktu yang lama untuk mengerjakannya.

Dengan demikian, penulis mencoba untuk memberikan solusi melalui suatu rancangan sistem baru[4], yakni dengan merancang suatu sistem informasi penjualan sparepart dan jasa Servis secara terkomputerisasi dengan menggunakkan bahasa pemrograman Visual Basic.Net dan basis data MySQL.

Berdasarkan uraian di atas, maka penulis tertarik untuk melakukan penelitian dengan judul : "Rancang Bangun Sistem Informasi Penjualan Sparepart dan Jasa Servis Motor" yang diharapkan akan memberikan efisiensi dan efektifitas kerja pada bengkel benneta motor.

\section{Metode Penelitian}

\subsection{Metode Penelitian}

Metode penelitian yang digunakan penulis dalam melakukan penelitian yaitu metode kualitatif deskriptif. Metode kualitatif deskriptif bertujuan membuat gambaran sistematis, faktual, dan akurat mengenai fakta-fakta dan sifat-sifat pada suatu objek penelitian tertentu. Metode deskriptif dalam melaksanakan penelitian sebagai acuan perancangan penelitian dan merupakan penjabaran dari awal perencanaan hingga tercapai tujuan penelitian[5]. Dalam melakukan pengumpulan data penulis menggunakan beberapa metode diantaranya Wawancara yang dilakukan terhadap pemilik dan karyawan pada bengkel benneta motor untuk melengkapi data yang dibutuhkan. Selain wawancara ,penuli juga melakukan observasi dengan cara melihat proses kerja yang terjadi pada lokasi penelitian . setelah melakuan observasi , penulis melakukan Studi Pustaka dengan cara mencari sumber dari berbagai buku serta referansi lain yang sesuai dengan adanya permasalahan yang diamati. Selain itu juga mencari sebuah informasi tambahan melalui jaringan internet.
Metode perancangan yang digunakan penulis dalam melakukan penelitian ini yaitu metode warterfall [6]. Adapun tahap - tahap dalam metode waterfall yang digunakan adalah sebagai berikut :

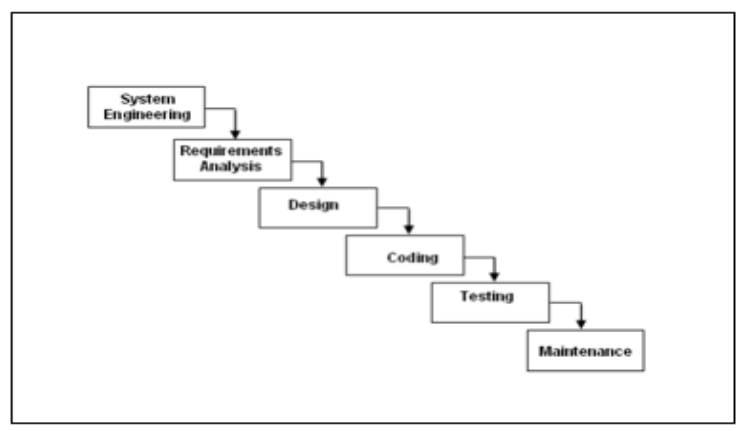

Gambar 1. Model Waterfall

a) Sistem engineering

Tahap ini dilakukan untuk mengetahui ruang lingkup permasalahan yang muncul pada bengkel kemudian penulis menetukan tujuan pembuatan sistem serta mengidentifikasi setiap kendala yang muncul.

b) Analisis

Pada tahap ini penulis melakukan analisa terhadap sistem yang sedang berjalan pada bengkel Benneta Motor agar dapat mengusulkan sistem baru yang diharapkan dapat memenuhi tugas yang belum mampu dilakukan oleh sistem yang sedang berjalan . selain itu penulis juga menetapkan analisa kebutuhan sistem yang akan dibangun dimulai dari analisa kebutuhan Software hingga Hardware.

c) Design (Perancangan)

Tahap perancangan sistem sesuai dengan teknik dan metode perancangan sistem yang digunakan dengan mengindahkan pemahaman sistem sebelumnya dan kriteria - kriteria sistem yang akan dibangun.

d) Coding (Pemrograman)

Pada tahap ini penulis menggunakan bahasa pemrograman Visual Basic.Net dan basis data MySQL sebagai tempat penyimpanan.

e) Testing (Pengujian)

Setelah tahapan coding selesai, penulis melakukan uji coba sistem yang telah dibangun dengan menggunakkan metode pengujian blacbox testing untuk memastikan bahwa sistem tersebut sudah benar atau sudah sesuai dengan karakteristik yang ditetapkan.

f) Maintenance (Pemeliharaan)

Pemeliharaan dapat dilakukan jika ada permintaan tambahan fungsi sesuai dengan keinginan pemakai ataupun adanya pertumbuhan dan perkembangan baik perangkat lunak maupun perangkat keras.

\subsection{Metode Perancangan Sistem}




\section{Hasil dan Pembahasan}

3.1 Perancangan Sistem

a) Usecase Diagram

Use case merupakan rancangan awal sistem informasi dimana terdapat admin yang dapat mengakses semua usecase yang ada pada sistem seperti : melakukan login, mengelola data master, transaksi, juga dapat melihat dan mencetak laporan serta melakukan logout .

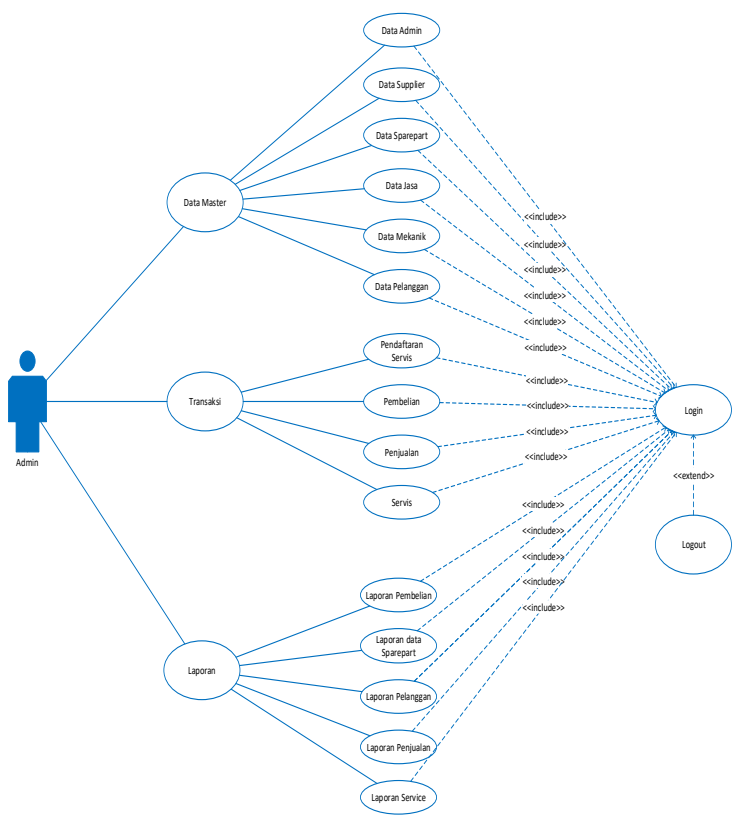

Gambar 2. Usecase Diagram

b) Relasi tabel

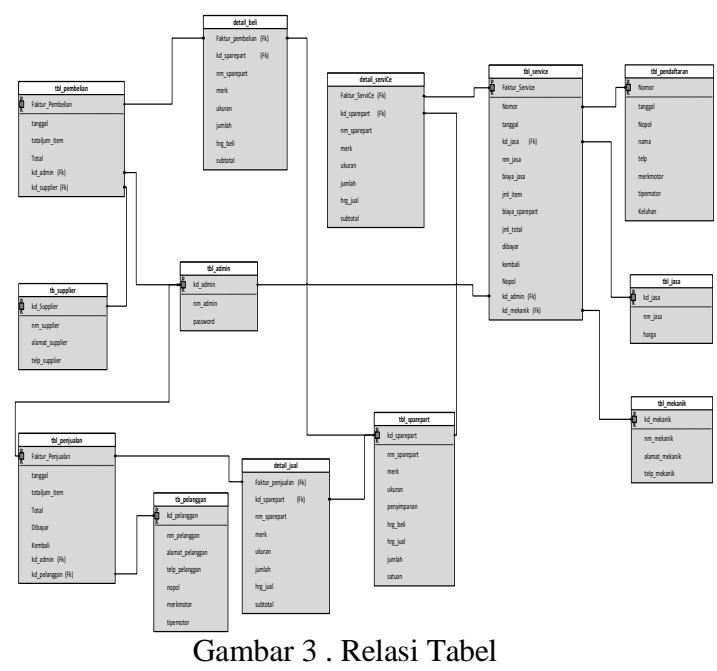

3.2 Implementasi sistem

Berikut ini adalah hasil implementasi dari Sistem Informasi Penjualan Sparepart dan Jasa Servis :

a) Implementasi Form Login

Form login berfungsi untuk memasukkan hak akses admin yang berisi user name dan password. Hanya admin yang telah memiliki user name dan password saja yang bisa mengakses sistem informasi ini demi keamanan sistem.

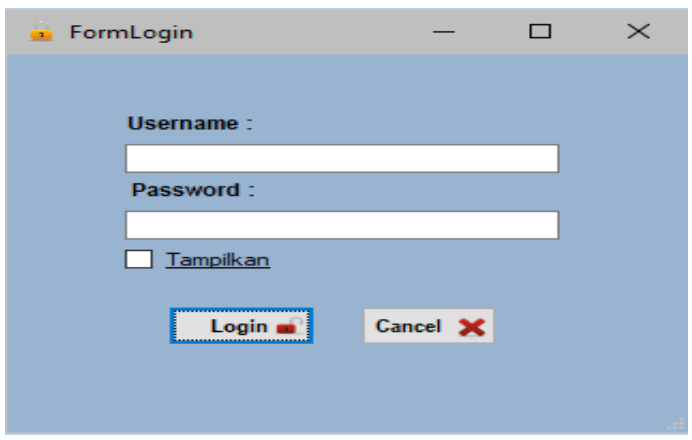

Gambar 4 . Implementasi Form Login

b) Implementasi Form Menu Utama

Apabila Admin behasil mengisi form login dengan benar maka akan tampil form Menu utama. disini admin dapat memilih beberapa menu sesuai dengan kebutuhan yang akan digunakan.

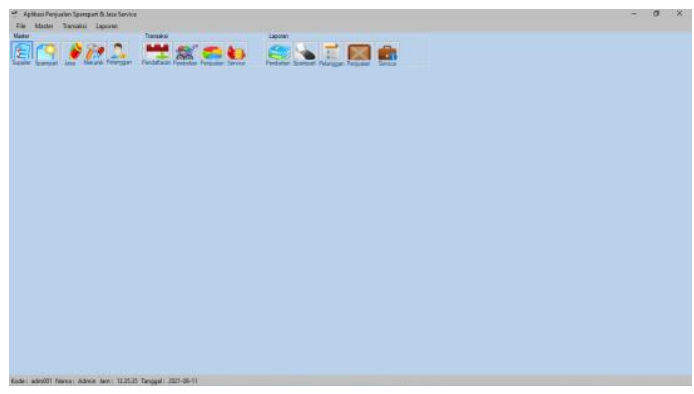

Gambar 5. Implementasi Form Menu Utama

c) Implementasi Form Master admin

Form Master admin digunakan untuk mengakses data admin . pada form ini admin dapat menambah, mengubah, dan menghapus data.

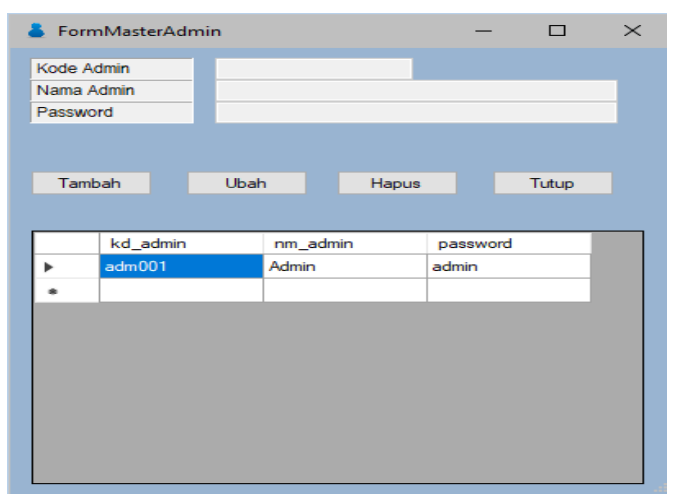

Gambar 6. Implementasi Form Master Admin

d) Implementasi Form Master Supplier Form Master Supplier digunakan untuk mengakses data supplier. pada form ini admin 
dapat menambah, mengubah, dan menghapus data supplier.

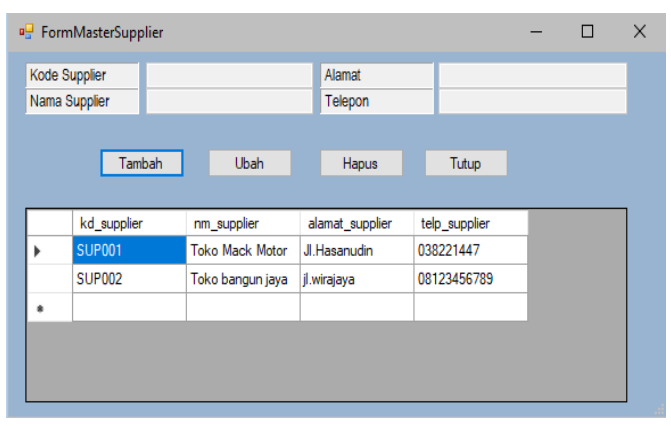

Gambar 7 . Implementasi Form Master Supplier

e) Implementasi Form Master Sparepart

Form Master Sparepart digunakan untuk mengakses data sparepart. pada form ini admin dapat menambah, mengubah, dan menghapus data sparepart.

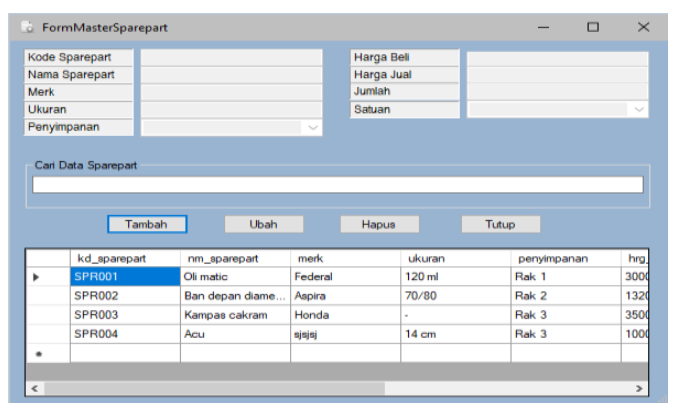

Gambar 8. Implementasi Form Master Sparepart

f) Implementasi Form Master Jasa

Form Master Jasa digunakan untuk mengakses data jasa . pada form ini admin dapat menambah , mengubah, dan menghapus data jasa.

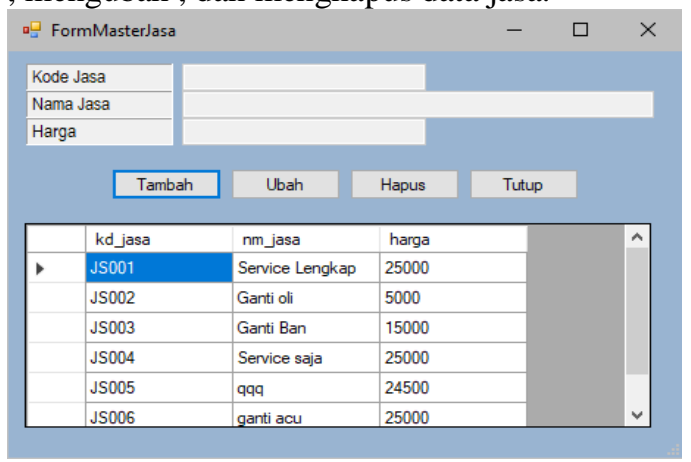

Gambar 9. Implementasi Form Master Jasa

g) Implementasi Form Master Mekanik

Form Master Mekanik digunakan untuk mengakses data supplier. pada form ini admin dapat menambah, mengubah, dan menghapus data mekanik.

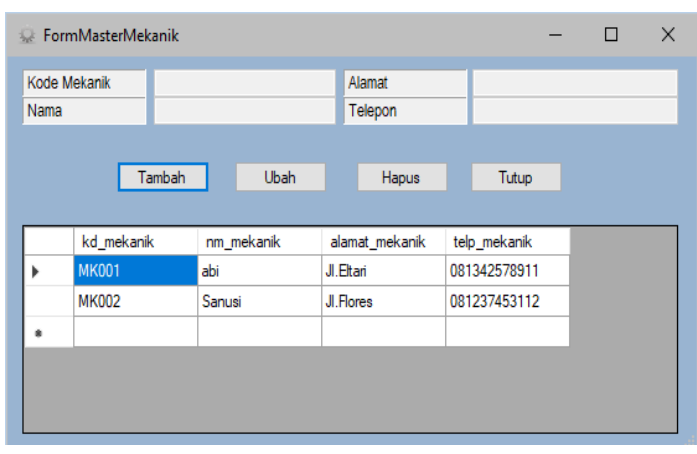

Gambar 10. Implementasi Form Master Mekanik

h) Implementasi Form Master Pelanggan Form Master Pelanggan digunakan untuk mengakses data supplier. pada form ini admin dapat menambah, mengubah, dan menghapus data pelanggan.

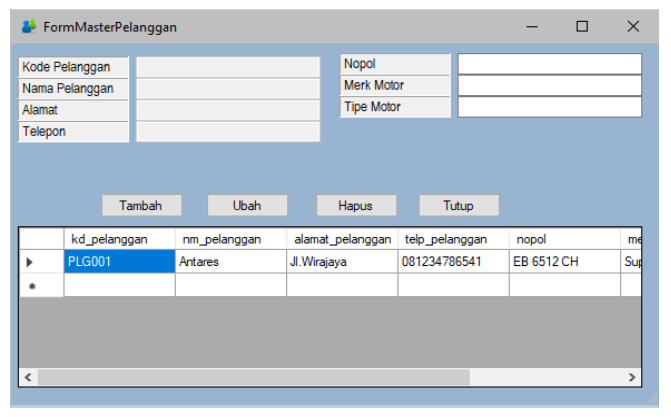

Gambar 11. Implementasi Form Master Pelanggan

i) Implementasi Form Pendaftaran Service Form pendaftaran service digunakan untuk pelanggan yang hendak melakukan service motor.

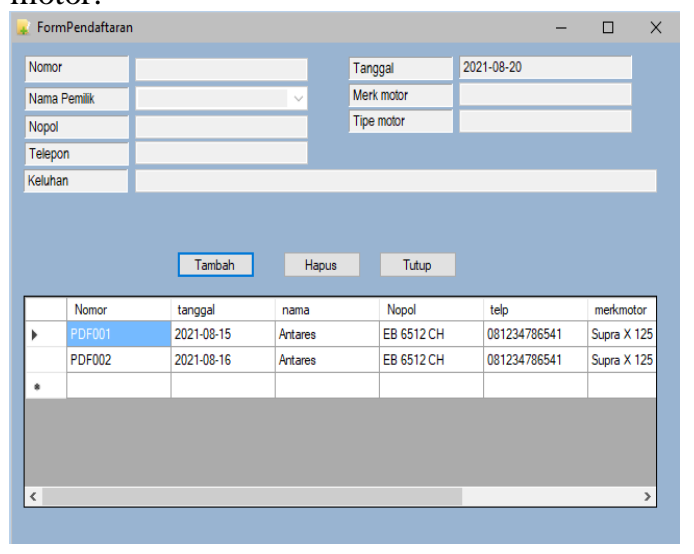

Gambar 11. Implementasi Form pendaftaran Service

j) Implementasi Form Transaksi Pembelian Form Transaksi Pembelian digunakan untuk mengakses data transaksi pembelian suku cadang sparepart. pada form ini admin dapat menambahkan dan menyimpan sparepart yang datang dari supplier. 


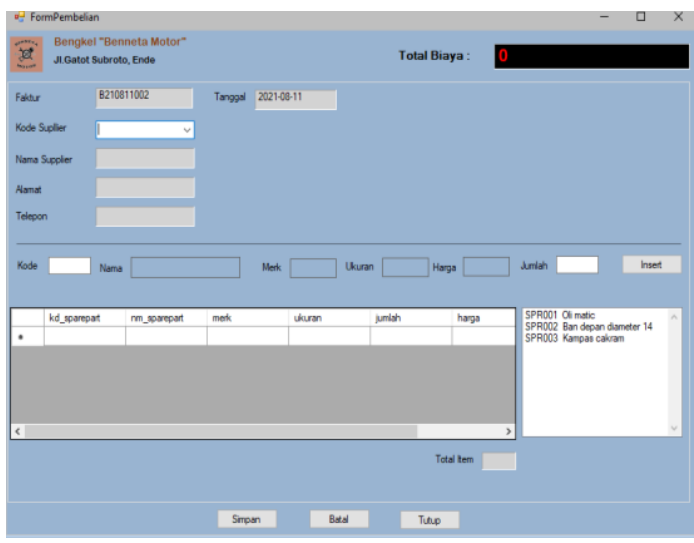

Gambar 12. Implementasi Form Transaksi Pembelian

k) Implementasi Form Transaksi Penjualan Form Transaksi penjualan digunakan untuk mengakses transaksi penjualan . pada form ini admin dapat menambahkan data penjualan sparepart dan mencetak nota penjaulan.

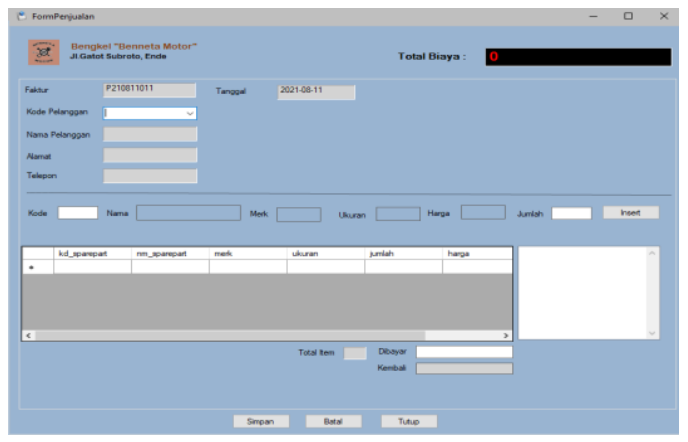

Gambar 13. Implementasi Form Transaki Penjualan

1) Implementasi Form Transaksi Service

Form Transaksi penjualan digunakan untuk mengakses transaksi service . pada form ini admin dapat menambahkan data service dan mencetak nota service.

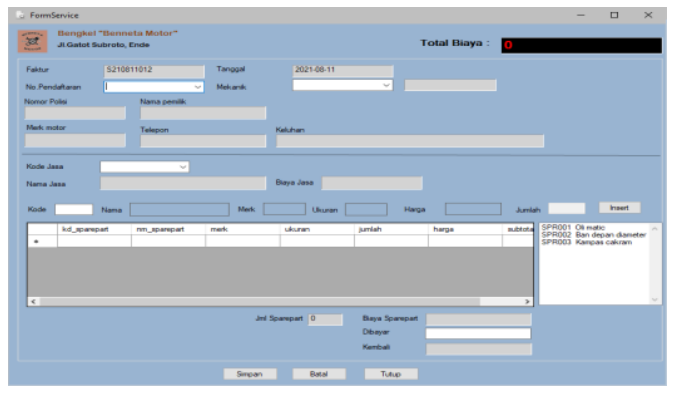

Gambar 14. Implementasi Form Transaksi Service

m) Implementasi Form Cetak Laporan Data Sparepart.
Pada Form ini admin dapat mencetak seluruh laporan data sparepart.

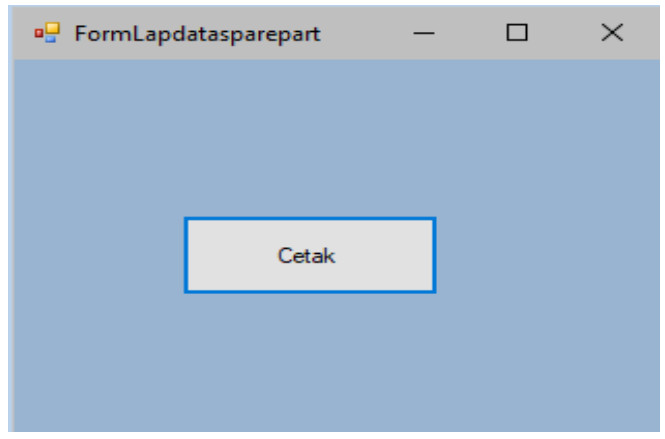

Gambar 15. Implementasi Form Cetak Laporan Data Sparepart

n) Implementasi Form Cetak Laporan Data Pelanggan.

Pada Form ini admin dapat mencetak seluruh laporan data pelanggan.

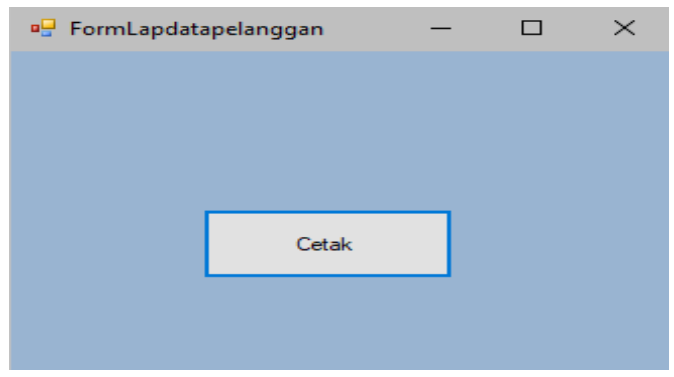

Gambar 15. Implementasi Form Cetak Laporan Data Pelanggan

o) Implementasi Form Cetak Laporan Pembelian Pada Form ini admin dapat mencetak laporan pembelian sesuai dengan nomor nota, laporan per minggu, perbulan hingga laporan per tahun .

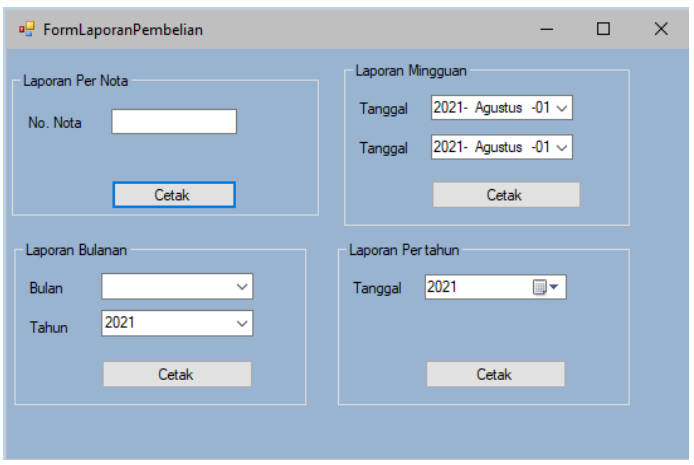

Gambar 16. Implementasi Form Cetak Laporan Pembelian

p) Implementasi Form Cetak Laporan Penjualan 
Pada Form ini admin dapat mencetak laporan penjualan sesuai dengan nomor nota, laporan per minggu, perbulan hingga laporan per tahun.

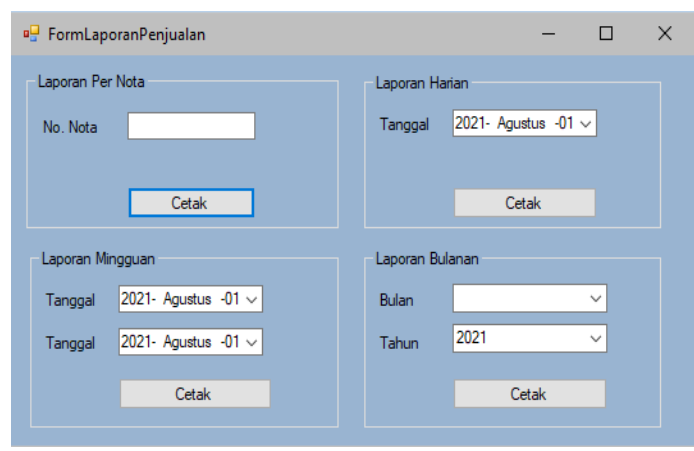

Gambar 18. Implementasi Form Cetak Laporan Penjualan

q) Implementasi Form Cetak Laporan Service Pada Form ini admin dapat mencetak laporan service sesuai dengan nomor nota, laporan per minggu, perbulan hingga laporan per tahun.

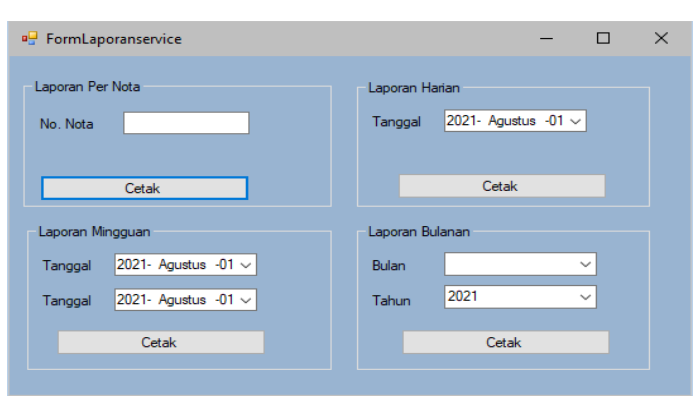

Gambar 19. Implementasi Form Cetak Laporan Service

\subsection{Pengujian}

Pengujian yang penulis lakukan dengan [4] menggunakan black box testing. Pengujian merupakan bagian yang penting dalam proses perancangan dalam membuat aplikasi bengkel ini. [5] Pengujian ini dimaksudkan untuk mengetest kualitas dan juga mengetahui kelemahan dari perangkat lunak sistem . Berdasarkan Hasil dari pengujian yang telah dilakukan dapat disimpulkan bahwa terdapat beberapa proses yang ada dalam [6] sistem mungkin saja masih memiliki beberapa kesalahan kecil dikarenakan dalam pengujian black- box memang tidak menampilkan pengujian sistem secara lebih detail. Namun apabila dilihat secara fungsinya. Sistem Informasi ini akan sangat membantu pihak bengkel dalam melakukan pengelolaan data, transksi, dan membuat laporan.

\section{Kesimpulan}

Dari hasil penelitian yang dilakukan penulis, maka dapat disimpulkan bahwa dengan adanya Sistem Informasi ini dapat membantu proses pengelolaan data yang terkait pada bengkel Benneta motor dan mempercepat proses transaksi pembelian, penjualan sparepart dan jasa service serta dapat memudahkan admin dalam mengecek atau mencetak laporan dikarenakan semua data bengkel tersimpan di dalam database sehingga memaksimalkan dan meminimalisir terjadinya kehilangan data.

\section{Ucapan Terima Kasih}

Peneliti mengucapkan limpah terima kasih kepada Kampus Universitas Flores dan Bengkel Benetta Motor yang selama ini telah membantu penulis dalam melaksanakan penelitian.

\section{Referensi}

[1] S. Bambang and I. Novita, "Pembelian Dan Pelayanan Jasa Service Dengan Object," pp. 79-84, 2017, [Online]. Available:

http://jom.fti.budiluhur.ac.id/index.php/IDEALIS/article/vi ew/119.

[2] M. Audrilia and A. Budiman, "Perancangan Sistem Informasi Manajemen Bengkel Berbasis Web (Studi Kasus : Bengkel Anugrah)," J. Madani Ilmu Pengetahuan, Teknol. dan Hum., vol. 3, no. 1, pp. 1-12, 2020, doi: 10.33753/madani.v3i1.78.

[3] D. Marsudi, A. Mufti, and M. Lestari, "Perancangan Sistem Aplikasi Penjualan Sparepart pada Toko Kim Jaya Motor," J. Ris. dan Apl. Mhs. Inform., vol. 1, no. 03, pp. 376-383, 2020, doi: 10.30998/jrami.v1i03.382.

A. Ahmad and A. Gunawan, "Perancangan sistem informasi service kendaraan bermotor (roda dua) pada bengkel xyz kota banda aceh," J. Informatic, Educ. Manag., vol. 3, no. 1, pp. 30-39, 2021.

M. Aman, "Pengembangan Sistem Informasi Wedding Organizer Menggunakan Pendekatan Sistem Berorientasi Objek Pada CV Pesta Wedding Organizer Information System using Object Oriented System Approach in CV Pesta," J. Janitra Inform. dan Sist. Inf., vol. 1, no. 1, pp. 47-60, 2021, doi: 10.25008/janitra.v1i1.119.

Verawati and P. D. Liksha, "Aplikasi Akuntansi Pengolahan Data Jasa Service," J. Sist. Inf. Akunt., vol. 1, no. 1, p. 3, 2018. 